๑ Entomologica Fennica. 20 December 1995

\title{
New species of fungus gnats (Diptera: Mycetophilidae) from the Kivach Nature Reserve, Russian Karelia
}

\author{
A. I. Zaitzev \& A. V. Polevoi
}

Zaitzev, A. I. \& Polevoi, A. V. 1995: New species of fungus gnats (Diptera: Mycetophilidae) from the Kivach Nature Reserve, Russian Karelia. - Entomol. Fennica 6:185-195.

Eleven new species of fungus gnats are described from Kivach Nature Reserve, Russian Karelia: Mycomya indistincta Polevoi sp.n., Boletina triangularis Polevoi sp.n., B. minuta Polevoi sp.n., B. populina Polevoi sp.n., B. onegensis Polevoi sp.n., Allodia vernalis Polevoi sp.n., Brevicornu neofasciculatum A. Zaitzev sp.n., B. setigerum A. Zaitzev sp.n., B. parafennicum A. Zaitzev sp.n., Dynatosoma dihaeta Polevoi sp.n., Phronia myrtilli Polevoi sp.n. Illustrations of male genitalia and ecological data are provided. Brevicornu improvisum A. Zaitzev is recorded for the first time from the Palearctic region.

A. I. Zaitzev, Institute of Evolutionary Animal Morphology and Ecology, Leninsky prosp., 33, 117071, Moscow, Russia

A. V. Polevoi, Forest Research Institute, Karelian Centre of Russian Academy of Sciences, Pushkinskaya 11, 185610, Petrozavodsk, Russia

Received 27 March 1993, accepted 31 March 1995

The Kivach Nature Reserve was established in 1931 in the territory of Russian Karelia. It is located 80 $90 \mathrm{~km}$ NNW of Petrozavodsk. The core zone of the reserve $\left(62^{\circ} 17^{\prime} \mathrm{N}, 33^{\circ} 59^{\prime} \mathrm{E}\right)$ occupies an area of 10,460 hectares. Coniferous forests of Scotch pine and Norway spruce prevail here, while the proportion of deciduous (birch and aspen) stands is about $25 \%$. A more lengthy description is published elsewhere (Salo 1986). The territory of the reserve for a long time has been used by biologists as an experimental area. Entomological research has been conducted here since the 1970s.

The first list of Diptera from the Kivach Nature Reserve was based on E.Yakovlev's experience in rearing specimens from macrofungi (Yakovlev 1986; including 76 fungus gnat species). Large scale trapping with Malaise and bait traps conducted in 1988-1990 (Yakovlev \& Myttus 1989,
Yakovlev \& Polevoi 1991a, 1991b) extended the list of Mycetophilidae to 188 species. The latter material has been collected mainly in pine stands of Vaccinium myrtillus and $V$. vitis-idaea types aged from 70 to 160 years. Young birch and aspen stands (40-50 years old) and an old spruce stand (160 years) were involved as well. Thorough examination of this material revealed eleven new species of fungus gnats; these new species are known only by the male characters, and therefore the descriptions below concern only the males. The type material is deposited in the Zoological Institute, St. Petersburg (ZIN), and in the Institute of Evolutionary Animal Morphology and Ecology, Moscow (IEAME).

In addition, one species new to the Palearctic region, Brevicornu improvisum A. Zaitzev, was found in the Kivach Reserve. 
Mycomya indistincta Polevoi sp.n.

Holotype ơ: Russia, Karelia, Kivach Nature Reserve, Yakovlev, 26.IX,-2.X.990; 1 o' paratype with same data; 1 ơ paratype: same place Polevoi, 9-20.X.990 (ZIN).

Head black. Mouthparts and palps brown. Antennae dark brown, The base of first flagellomere lighter. Sixth flagellomere 3 times as long as wide.

Thorax. Pleurae dark brown, anterior spiracles yellowish brown. Mesonotum black with brown lateral margins. Scutellum brown with 4 long setae. Laterotergite bare, mediotergite with 1-2 short bristles.

Legs entirely brown. Fore coxa without special setae. Mid coxa with curved spur, reaching about a half of coxa length and bearing single apical tooth (Fig. 1). Leg ratios: t1:bt1 $=0.97$, $\mathrm{t} 2: \mathrm{bt} 2=1.3, \mathrm{t} 3: \mathrm{bt} 3=1.57$.

Wings. Wing length $-5 \mathrm{~mm}$. Wings hyaline, Sc bare, ending in Costa distally middle of small cell, Sc2 ending in R1 distally middle of small cell. Small cell 4 times as long as wide. Cubital fork proximal to Median fork. Stem of Median fork 8 times as long as RM. Haltere yellowish brown.

Abdomen brown. Male genitalia (Fig. 1) brown. Medial processus of tergite IX with two dense apical combs of thin setae and pair of setose basal appendages. Tergal lateral appendages long, bearing short hairs on inner surface. Sternal lateral appendages broad and short, sternal submedian appendages indistinct. Gonostylus unbranched, curved apically, bearing 2-3 short bristles in central part.

Remarks. $M$. indistincta can probably be referred to the marginata-group, considering affinity of external characters (lack of special setae on fore coxa, midcoxal spur, position of Cubital fork, diffusely dark coloration of abdomen) and general hypopygium structure, but differs from the remaining species in lack of sternal submedian appendages and unbranched, toothless gonostylus, which is unusual for representatives of this group (Väisänen 1984). Collected with Malaise traps in Myrtillus pine and birch stands.

Dr. Chandler informed us about two specimens of Mycomya stored in the Natural History Museum, London: they are conspecific with $M$. indistincta. The data of that material is as follows: $1 \sigma^{7}$, Finland, Ab., north of Parainen, mixed woods, 8.X.1979 (P. Chandler); $1 \sigma^{7}$, Andorra, Encamp, IX.1935 (F.W. Edwards).

\section{Boletina triangularis Polevoi, sp.n.}

Holotype ơ: Russia, Karelia, Kivach Nature Reserve, Yakovlev, 9-20.X.990; 18 ơ paratypes with same data; 2 ơ paratypes: same place Polevoi, 26.IX.-2.X.990; 16 o paratypes: same place Polevoi, 17-24.VI, 20.IX.-15.X.991 (ZIN).

Head black. Mouth parts and palps dark brown. Antennae dark brown, first flagellomere lighter. Sixth flagellomere 3 times as long as wide.

Thorax. Mesonotum and pleurae black, grey dusted, anterior spiracles yellowish brown. Laterotergite bare.

Legs. Coxae, femora, tibiae and tarsi yellow, trohanters brown. Leg ratios: $\mathrm{tl}: \mathrm{bt} \mathrm{l}=1.3$, $\mathrm{t} 2: \mathrm{bt} 2=1.4, \mathrm{t} 3: \mathrm{bt} 3=1.7$.

Wings. Wing length $-7.9-8.5 \mathrm{~mm}$. Wings hyaline, Sc2 present, Costa extending well beyond the tip of R4+5, stem of Median fork 1.5 times as long as RM. Haltere yellow.

Abdomen dark brown. Male genitalia (Fig. 2) dark brown. Gonostylus bearing four apical spines, medial processes of gonocoxites short, triangular. Tergite IX oval, with distal margin slightly concave. Cerci covered with irregularly arranged spines. Parameres with apical tooth.

Remarks. B. triangularis refers to sciarinagroup and differs from the rest species in structure of hypopygium. Collected with Malaise traps in different types of pine stands.

\section{Boletina minuta Polevoi sp.n.}

Holotype ơ: Russia, Karelia, Kivach Nature Reserve, Polevoi, 2-9.X.990; 2 ơ paratypes with same data; $10^{7}$ paratype: same place Polevoi, 9-20.X.990; 1 \% paratype: same place Polevoi, 18-21.V.989 (ZIN).

Head black. Mouthparts and palps dark brown. Antennae dark brown. Sixth flagellomere 3-3.5 times as long as wide.

Thorax. Pleurae brown, mesonotum black, grey dusted, with brown lateral margins. Laterotergite bare.

Legs. Coxae and femora yellow, tibiae and tarsi brownish. Leg ratios: $\mathrm{t} 1: \mathrm{bt} 1=1.3, \mathrm{t} 2: \mathrm{bt} 2=1.3$, $\mathrm{t} 3: \mathrm{bt} 3=1.6$.

Wings. Wing length $-2.8-4 \mathrm{~mm}$. Wings hyaline, $\mathrm{Sc} 2$ present, Costa extending well beyond the tip of $\mathrm{R} 4+5$, stem of Median fork 1.5 times as long as RM. 


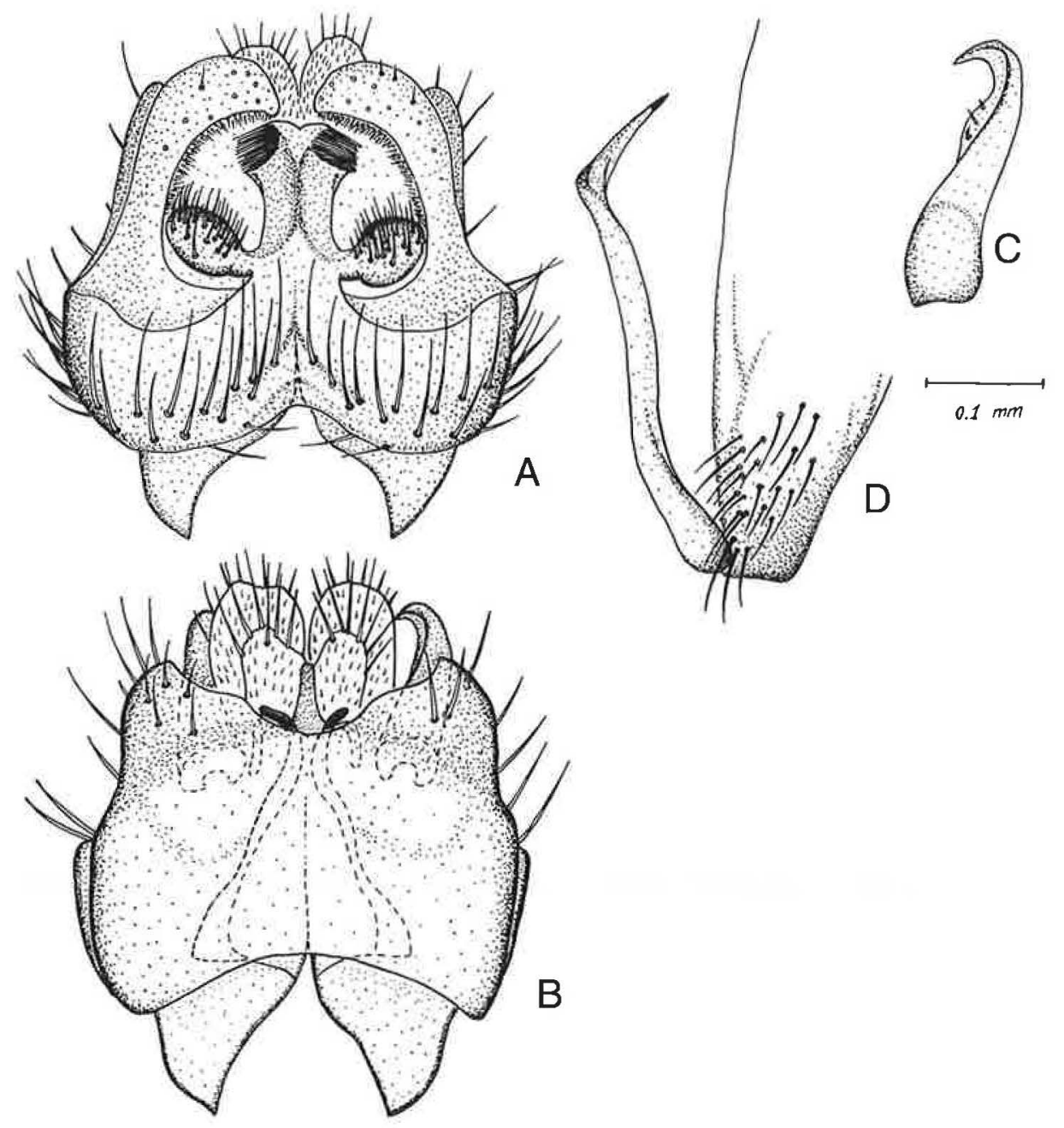

Fig. 1. Mycomya indistincta Polevoi sp.n. A: male hypopygium, tergal view; B: hypopygium, sternal view; C: gonostylus; D: male mid coxa. — Scale line $0.1 \mathrm{~mm}$.

Abdomen dark brown. Male genitalia (Fig. 2) dark brown. Gonostylus with five apical spines, medial processes of gonocoxites long and narrow. Tergite IX slightly narrowed toward apex, with concave distal margin. Cerci egg-shaped, with apical comb of spines and basal group of smaller spines. Parameres comparatively short, tapered.

Remarks. $B$. minuta is close to previous species from which differs in details of hypopigium structure. Collected with Malaise traps in birch and aspen stands.
Boletina populina Polevoi sp.n.

Holotype ơ: Russia, Karelia, Kivach Nature Reserve, Polevoi, 4-12.X.989 (ZIN).

Head black. Mouthparts and palps dark brown. Antennae dark brown. Sixth flagellomere 2.5 times as long as wide.

Thorax. Mesonotum and pleurae black, grey dusted, laterotergite bare.

Legs. Femora, tibiae and tarsi dark yellow, coxae brownish basally. Leg ratios: $\mathrm{t} 1 \mathrm{bt} 1=1.33$, 

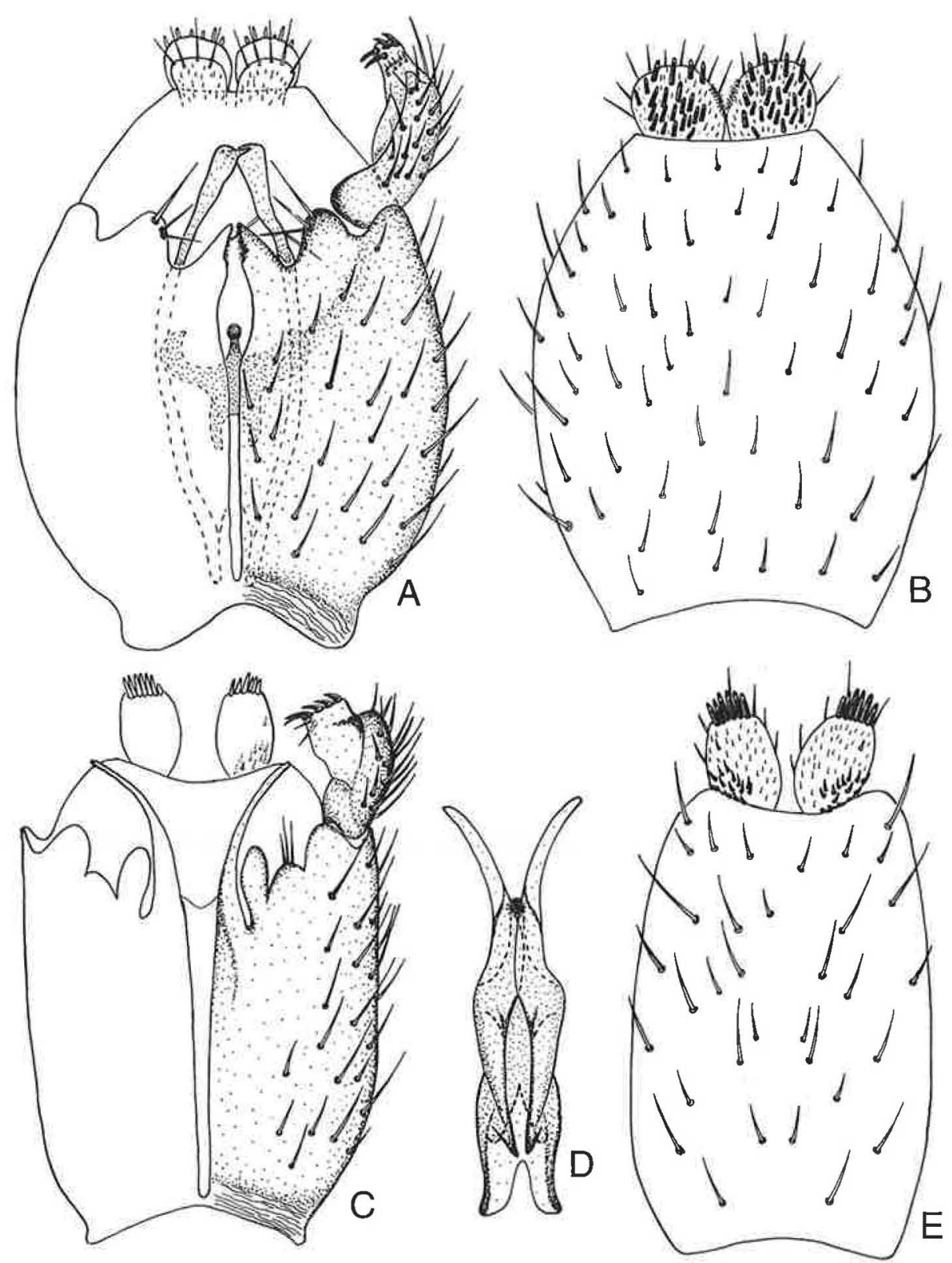

Fig. 2. Boletina triangularis Polevoi sp.n. A: male hypopygium, sternal view; B: tergite IX. Boletina minuta Polevoi sp.n. C: male hypopygium, sternal view; D: aedeagus; E: tergite IX. — Scale as in Fig. 1.

$\mathrm{t} 2: \mathrm{bt} 2=1.4, \mathrm{t} 3: \mathrm{bt} 3=1.7$.

Wings. Wing length $-4.2 \mathrm{~mm}$. Wings hyaline, $\mathrm{Sc} 2$ present, Costa extending well beyond the tip of $\mathrm{R} 4+5$, stem of Median fork 1.7 times as long as RM. Haltere yellowish brown.
Abdomen dark brown. Male genitalia (Fig. 3) brown. Gonostylus with four apical spines, medial processes of gonocoxites comparatively long, tapered. Distal margin of tergite IX with broad triangular depression. Cerci bearing 3-4 

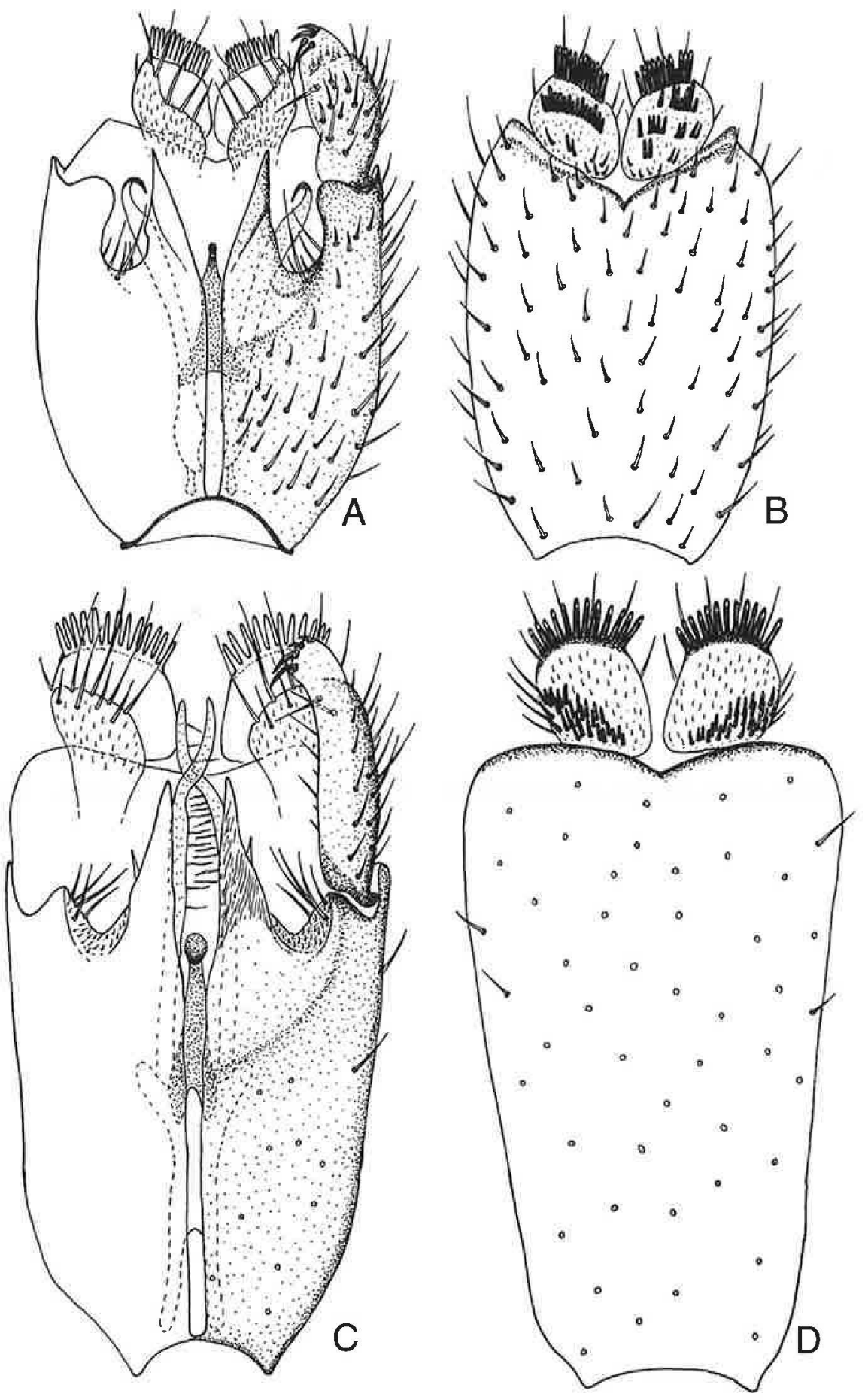

Fig. 3. Boletina populina Polevoi sp.n. A: male hypopygium, sternal view; B: tergite IX. Boletina onegensis Polevoi sp.n. C: male hypopygium, sternal view; D: tergite IX. — Scale as in Fig. 1. 

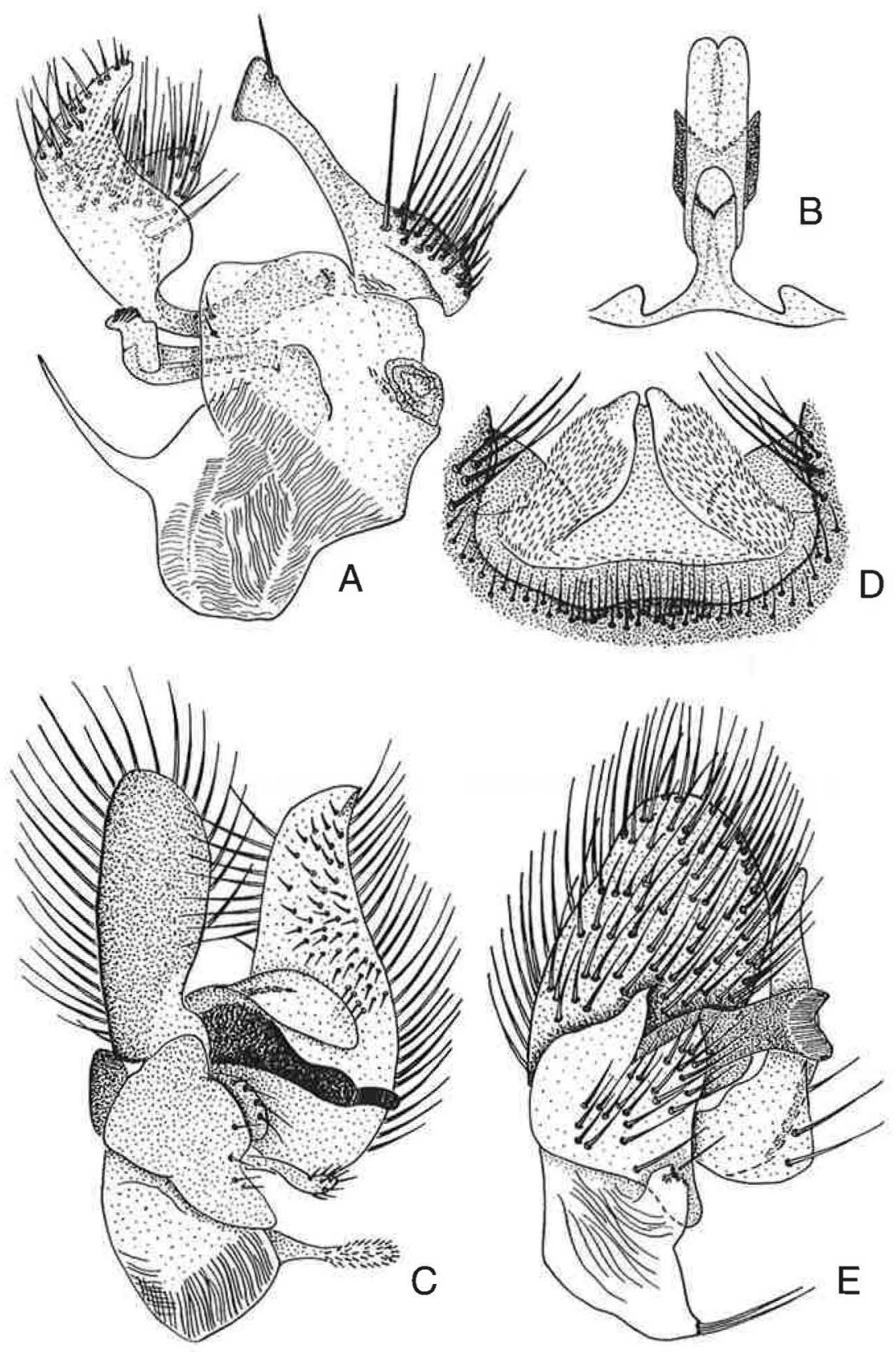

Fig. 4. Allodia vernalis Polevoi sp.n. A: gonostylus; B: ventral processus of gonocoxites. Brevicornu neofasciculatum A. Zaitzev sp.n. C: gonostylus; D: ventral processus of gonocoxites. Brevicornu setigerum A. Zaitzev sp.n. E: gonostylus. - Scale as in Fig. 1. 


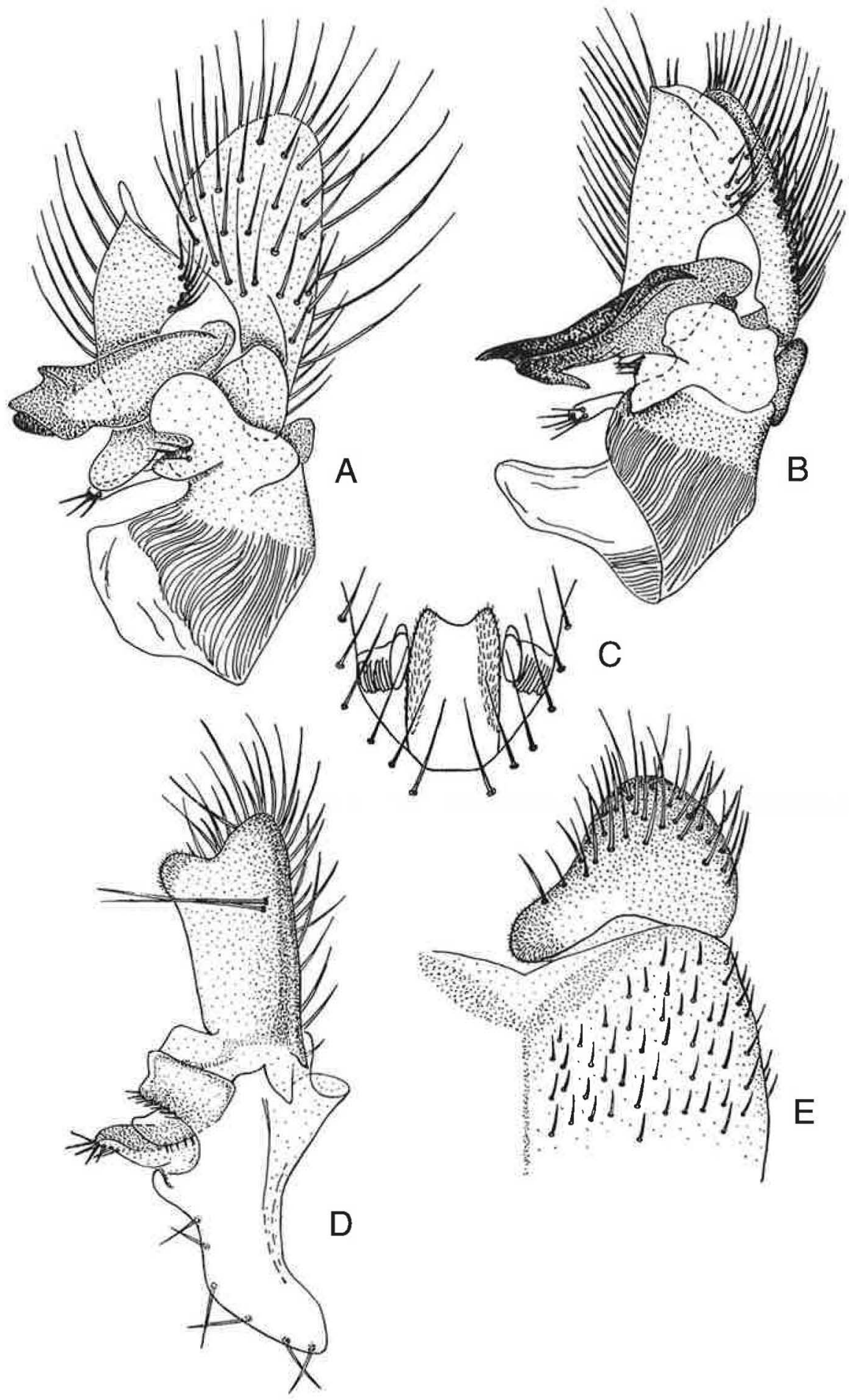

Fig. 5. Brevicornu parafennicum A. Zaitzev sp.n. A: gonostylus. Brevicornu improvisum A. Zaitzev sp.n. B: gonostylus; C: ventral processus of gonocoxites. Dynatosoma dihaeta Polevoi sp.n. D: gonostylus, dorsal view; E: male hypopygium, ventral view. - Scale as in Fig. 1. 
combs of spines. Parameres comparatively short, twisted apically.

Remarks. B. populina resembles B. sciarina Staeger, but differs in shorter parameres and more numerous rows of small spines on cerci. Collected with Malaise trap in aspen stand.

\section{Boletina onegensis Polevoi sp.n.}

Holotype ơ: Russia, Karelia, Kivach Nature Reserve, Yakovlev, 9-20.X.990; $4 \sigma^{7}$ paratypes with same data; $4 \sigma^{7}$ paratypes: same place Polevoi, 13.VIII.-9.X.990 (ZIN).

Head black. Mouthparts and palps dark brown. Antennae dark brown. Sixth flagellomere 3 times as long as wide.

Thorax. Mesonotum and pleurae black, grey dusted, anterior spiracles yellowish brown. Laterotergite bare.

Legs yellowish brown. Leg ratios: $\mathrm{t} 1: \mathrm{bt} 1=1.4$, $\mathrm{t} 2: \mathrm{bt} 2=1.5, \mathrm{t} 3: \mathrm{bt} 3=1.8$.

Wings. Wing length $-3.6-4 \mathrm{~mm}$. Wings hyaline, Sc2 present, Costa extending well beyond the tip of R4+5, stem of Median fork 1.5 times as long as RM. Haltere yellowish brown.

Abdomen dark brown. Male genitalia (Fig. 3) dark brown. Gonostylus with four apical spines, medial processes of gonocoxites long, tapered. Distal margin of tergite IX with small triangular depression. Cerci with apical comb of spines and basal group of smaller spines. Parameres long, bent apically, covered with long fine hairs.

Remarks. $B$. onegensis is close to $B$. sciarina Staeger, from which it differs in pilose parameres and character of cercal spines allocation. Collected with Malaise traps in different types of pine stands.

\section{Allodia vernalis Polevoi sp.n.}

Holotype o': Russia, Karelia, Kivach Nature Reserve,

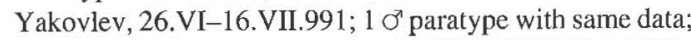
1 ơ paratype: same place Polevoi, 6.VI.-16.VII.991 (ZIN).

Head dark brown. Clypeus, mouthparts and palps yellow. Antennae brown, scape, pedicel and first flagellomere yellow. Sixth flagellomere about as long as wide.

Thorax. Lateral parts of prothorax yellow. Sternopleuron and pteropleuron yellowish brown.
Mesopleuron, laterotergite and mediotergite brown. Mesonotum dark brown with yellow humeral spots.

Legs yellow. Leg ratios: t1:bt $1=0.9$, $\mathrm{t} 2 \mathrm{bt} 2=0.9, \mathrm{t} 3: \mathrm{bt} 3=1.4$. Mid tibiae with $16 \mathrm{a}, 3 \mathrm{~d}$, $6 \mathrm{p}, 4 \mathrm{pv}$. Hind tibiae with $10-13 \mathrm{a}, 6-7 \mathrm{~d}$.

Wings. Wing length $-2.7-3.1 \mathrm{~mm}$. Wings hyaline, stem of Median fork as long as RM. Base of Cubital fork well before the base of RM. Haltere yellow.

Abdomen dark brown. Tergites I-V with yellow spots. Male genitalia (Fig. 4) yellow. Medial lobe of gonostylus dilated apically. Lateral lobe of gonostylus with strong apical seta.

Remarks. A. vernalis is apparently identical to A. retracta sensu Plassmann (1977a). However, the species carefully depicted later under the same name by Caspers and Plassmann (1986) differs distinctly in absence of strong apical seta on lateral lobe of gonostylus. Dr. Chandler informed us that Plassman's type series probably consisted of two different species, which he deduced from correspondence with Dr. Caspers, and that there was no response to his request to examine the specimens. The present description thus provides a name for the species figured by Plassmann. $-A$. vernalis was reared from fruiting bodies of Peziza badia Fr. and Discina perlata (Fr.) Harmaja.

\section{Brevicornu neofasciculatum A. Zaitzev sp.n.}

Holotype ơ: Russia, Karelia, Kivach Nature Reserve, Polevoi, 13.VIII-11.IX.990; 1 ơ paratype with same data;1 ơ paratype: same place Polevoi, 11-18.IX.990 (IEAME).

Head dark brown with yellow mouthparts. Antennae brown, scape, pedicel and first flagellomere yellow. Sixth flagellomere about as long as wide.

Thorax. Pleurae yellow, propleuron with five bristles. Mediotergite brown. Mesonotum yellow with three dark fused strips. Scutellum brown with four scutellar bristles.

Legs yellow. Fore basitarsus about as long as fore tibia. Mid tibia with 12 a, 4 d, 8 p. Hind tibiae with 14 a, 5 d, 4 p.

Wings. Wing length $-2.8 \mathrm{~mm}$. RM 1.5 times as long as stem of Median fork. Base of Cubital fork well before the base of RM. Haltere yellow.

Abdomen dark brown. Tergites III, IV with yellow lateral spots. Male genitalia (Fig. 4) yellow.

Remarks. $B$. neofasciculatum is close to $B$. fasciculatum (Lackschewitz), from which distin- 
Fig. 6. Phronia myrtilli Polevoi sp.n. A: male hypopygium, ventral view; B: gonostylus. - Scale as in Fig. 1.

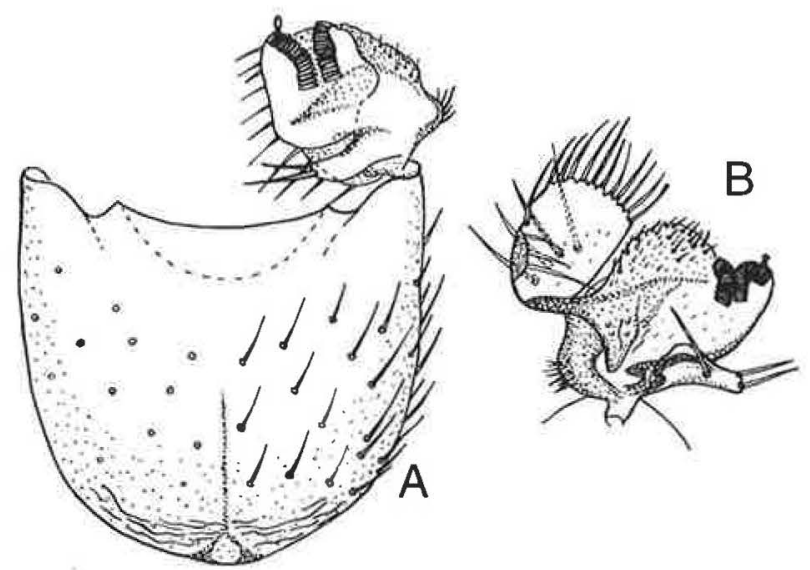

guished by the shape of sternal processus of gonocoxites, medial lobe of gonostylus and lack of strong apical bristles on dorsal lobe of gonostylus.

\section{Brevicornu setigerum A. Zaitzev sp.n.}

Holotype 07: Russia, Karelia, Kivach Nature Reserve, Polevoi, 24.VIII-25.IX.989 (IEAME).

Head dark brown with yellow mouthparts. Antennae brown, scape, pedicel and two basal flagellomeres yellow. Sixth flagellomere about as long as wide.

Thorax. Propleuron yellowish with three long bristles. Mesonotum light brown with yellow humeral region. Scutellum brown with four scutellar bristles.

Legs yellow. Fore basitarsus slightly shorter than fore tibia. Mid tibia with 7 a, 3 d, 6 p. Hind tibiae with 10 a, $4 \mathrm{~d}$.

Wings. Wing length $-2.7 \mathrm{~mm}$. RM about as long as stem of Median fork. Base of Cubital fork well before the base of RM. Haltere yellow.

Abdomen dark brown. Tergites II-IV with yellow lateral spots. Male genitalia (Fig. 4) yellow.

Remarks. B. setigerum belongs to proximumgroup and can be distinguished from the rest of the species by presence of numerous bristles on internal lobe of gonostylus.

\section{Brevicornu parafennicum A. Zaitzev sp.n.}

Holotype o : Russia, Karelia, Kivach Nature Reserve, Polevoi, 24.VIII-25.IX.989 (IEAME).
Head dark brown with yellow clypeus and mouthparts. Antennae brown, scape, pedicel and three basal flagellomeres yellow. Sixth flagellomere about 1.3 times as long as wide.

Thorax. Mesonotum yellow with three dark fused strips. Scutellum brown with two long and two short scutellar bristles.

Legs yellow. Fore tibia about 1.2 times as long as fore basitarsus. Mid tibia with $7 \mathrm{a}, 2 \mathrm{~d}$, 5 p. Hind tibiae with 10 a, $3 \mathrm{~d}, 4$ pd.

Wings. Wing length $-2.6 \mathrm{~mm}$. Stem of Median fork about 1.3 times as long as RM. Base of Cubital fork well before the base of RM. Haltere yellow.

Abdomen dark brown. Tergites II-IV with yellow lateral spots. Male genitalia (Fig. 5) yellow.

Remarks. $B$. parafennicum is close to $B$. fennicum (Landrock), from which it differs in lack of horn-shaped internal lobe of gonostylus and in shape of ventral lobe of gonostylus.

\section{Brevicornu improvisum A. Zaitzev}

Brevicornu improvisum A. Zaitzev, 1992:13.

1 ơ. Russia, Karelia, Kivach Nature Reserve, Humala, 17.VIII.990 (IEAME).

Head dark brown with light brown clypeus and yellow mouthparts. Antennae brown, scape, pedicel and three basal flagellomeres yellow. Sixth flagellomere about twice as long as wide.

Thorax. Pleurae light brown. Mediotergite brown. Propleuron with two bristles. Mesonotum dark brown with yellow humeral region. Scutellum 
dark brown with four long scutellar bristles.

Legs yellow. Fore basitarsus about as long as fore tibia. Mid tibia with $5 \mathrm{ad}, 4 \mathrm{pd}, 7 \mathrm{p}$. Hind tibia with 6 ad, $4 \mathrm{~d}, 7 \mathrm{p}$.

Wings. Wing length $-2.7 \mathrm{~mm}$. Stem of Median fork about 1.5 times as long as RM. Base of Cubital fork under the middle of stem of Median fork. Haltere yellow.

Abdomen dark brown. Tergites II,III with small yellow lateral spots. Male genitalia (Fig. 5) yellow.

Remarks. B. improvisum was described from USA, Alaska (Zaitzev 1992). The discovery of this species in Karelia indicates that the species has a circumpolar distribution.

\section{Dynatosoma dihaeta Polevoi sp.n.}

Holotype $0^{7}$ : Russia, Karelia, Kivach Nature Reserve, Polevoi, 13.VIII-11.IX.990; 5 § paratypes with same data; 5 o7 paratypes: same place, Polevoi, 2-8.VIII.990, 26.VII.3.IX.991 (ZIN).

Head black, Mouthparts and palps yellow. Antennae dark brown, scape and pedicel yellowish brown. Sixth flagellomere about as long as wide.

Thorax. Pleurae black, prothoracic spiracles yellow. Mesonotum shining black.

Legs yellow. Mid and hind coxae darkened at the base. Mid and hind femorae darkened at the base and in apical quarter. Mid and hind tibiae darkened apically. Leg ratios: $t 1$ :bt1 $=0.95$, $\mathrm{t} 2: \mathrm{bt} 2=1.4, \mathrm{t} 3: \mathrm{bt} 3=1.8$. Fore tibiae with $2-3$ ventral bristles. The length of longest one exceeding diameter of tibia in apical part. Mid tibiae with 6 ad, 5 d, 5 pd, 2 v. Hind tibiae with 5 ad, $4 \mathrm{~d}, 5$ pd. Ventral bristles on hind tibia considerably weaker and shorter than dorsal ones.

Wings. Wing length $-3.9-5.1 \mathrm{~mm}$. Wings hyaline with well developed central spot and subapical band. Base of Cubital fork well beyond the base of Median fork. Haltere yellow.

Abdomen shining black. Tergites II-V with narrow yellow posterior bands. Male genitalia (Fig. 5) dark brown. Ventral lobe of gonostylus with two long bristles on inner surface.

Remarks. $D$. dichaeta is closely related to $D$. nigromaculatum Lundström and $D$. ussuriense A. Zaitzev, which also have one long ventral bristle on fore tibia and weak ventral bristles on hind tibia (Zaitzev 1986).D. dichaeta can, however, be easily separated from the others by its ventral lobe of gonostylus bearing two long bristles on inner surface. - Collected with Malaise traps in Myrtillus pine and birch stands.

\section{Phronia myrtilli Polevoi sp.n.}

Holotype of: Russia, Karelia, Kivach Nature Reserve, Yakovlev, 28.VI.-7.VII.990; 12 Ơ paratypes with same data (ZIN).

Head dark brown. Mouthparts and palps light brown. Antennae brown, scape, pedicel and first flagellomere lighter. Sixth flagellomere 1.5 times as long as wide.

Thorax dark brown. Mesonotum dull, pleurae slightly shining.

Legs. Mid and hind coxae dark brown, fore coxae lighter. Femora, tibiae and tarsi brown. Leg ratios: $\mathrm{t} 2: \mathrm{bt} 2=1.4$.

Wings. Wing length $-2.3 \mathrm{~mm}$. Wings hyaline, Sc short ending free. Haltere yellow.

Abdomen dark brown. Male genitalia. Fig. 22-23, dark brown. Caudoventral margin of gonocoxites almost straight. Lateral lobe of gonostylus with basoventral projection, bearing 2 apical bristles.

Remarks. $P$. myrtilli resembles $P$. cornuta Lundström, which possesses a similar colouration pattern (Plassmann 1977b) and according to the key by Gagné (1975) it runs to a mixed group of species having lateral lobe of gonostylus with basoventral projection bearing 2 apical bristles. $P$. myrtilli, nevertheless, differs distinctly in details of gonostylus structure. - Collected with Malaise traps in Myrtillus pine stand.

Acknowledgments. The authors are indebted to Lic. Phil. Gunilla Ståhls (Zoological Museum, University of Helsinki), Dr. Peter Chandler (Weston Research Laboratories, Maidenhead) and Dr. Evgenii Yakovlev (Forest Research Institute, Petrozavodsk) for comments on the manuscript and valuable information.

\section{References.}

Caspers, N. \& Plassmann, E. 1986: Jüngere Synonyme in der Untergattung Allodia (Brachycampta) Winnertz 1863. - Senckenbergiana Biol. 66:255-260.

Gagné, R. J. 1975: A revision of the Nearctic species of the 
genus Phronia (Diptera: Mycetophilidae). - Trans. Amer. Entomol. Soc. 101:227-318.

Plassmann, E. 1977a: Neue Pilzmücken aus dem Allgäu (Diptera, Mycetophilidae). - Nachrichtenblatt der Bayeischen. Entomologen 26(1):11-14.

- 1977b: Revision der europäischen Arten der Pilzemückengattung Phronia (Diptera: Mycetophilidae). Dtsch. Entomol. Ztschr., N. F. 24(IV-V):305-344.

Salo, K. 1986: Kivatsu, nature reserve in the Karelian Autonomic Socialist Republik. - Luonnon Tutkija 90:100-106 (In Finnish, English Summary).

Väisänen, R. 1984: A monograph of the genus Mycomya Rondani in the Holarctic region (Diptera, Mycetophilidae), - Acta Zool. Fennica 177:1-346.

Yakovlev, Е. В. (Яаковлез, Е. Б.) 1986: [Mycetobiont insects of South Karelia (ecology-faunistic list)]. - In Yakovlev, E. В. \& Uzenbajev, S. D. (Яаковлев, Е. Б. \& Узенбаев, С. Д.) (eds.): [Fauna and ecology of Karelian arthropods]; Karelian branch of the USSR Acad. Sci., Petrozavodsk, pp. 83-123 (in Russian).

Yakovlev, E. B. \& Myttus, E. R. 1989: On the attraction of insects by the fungal sporophores and by some fungal smell constituents. - Karelian branch of the USSR Acad. Sci., Petrozavodsk, 48 pp. (in Russian, English summary).

Yakovlev, E. B. \& Polevoi, A. V. 1991 a: Diptera from Malaise traps in pine and aspen forests. - In Yakovlev, E. B. \& Mozolevskaya, E. G. (eds.): Entomological researches in "Kivach" nature reserve; Karelian Centre of the USSR Acad. Sci., Petrozavodsk, pp. 5-30 (in Russian, English summary).

- 1991b: Insects attracted by the fungal baits. - In Yakovlev, E. B. \& Mozolevskaya, E. G. (eds.): Entomological researches in "Kivach" Nature Reserve; Karelian Centre of the USSR Acad. Sci., Petrozavodsk, pp. 45-65 (in Russian, English summary).

Zaitzev, A. I. 1986: Fungus Gnats of the Genus Dynatosoma (Diptera, Mycetophilidae) of the USSR Fauna. Vestn. Zool 4:34-41 (in Russian, English summary).

- 1992: New species of fungus gnats genera Allodia and Brevicomu (Diptera, Mycetophilidae) from North America. — Vestn. Zool. 1:9-15 (in Russian, English summary). 